\title{
A Mini Review on Paclitaxel Producing Fungal Strains
}

\section{Tiwari $K^{*}$}

Management and Science University, Malaysia

*Corresponding author: Kartikeya Tiwari, Associate Professor, IMS and FHLS, Management and Science University, Malaysia, Email: tiwarikartik1@gmail.com

\section{Mini Review}

Volume 2 Issue 7

Received Date: September 07, 2018

Published Date: September 28, 2018

DOI: $10.23880 /$ jonam-16000151

\section{Abstract}

Since the discovery of penicillin by Sir Alexander flemming. The new era of antibiotic producing fungi came into the picture. Paclitaxel is an anticancerous compound and it is widely accepted in hospitals and clinics. Recently a large number of fungi are potential paclitaxel producers were harnessed. In this mini review paclitaxel producing fungal strains are discussed in detail

Keywords: Paclitaxel; Potentialistic Fungal Strains; Anticancerous Compound

\section{Introduction}

There is a need of natural products all over the world. Synthetic drugs possess large number of side effects, therefore the scientific world started focusing on natural products now a days. The drugs of plant origin harnessed at maximum level in the past. New strategies and concepts to be developed and new fungal strains must be discovered for the drug production. Paclitaxel is an anticancerous compound produced by various endophytic fungal strains and yew tree. This compound is found in yew trees and these plants usually destroyed to extract paclitaxel in recent years [1-7]. So if the new endophytic fungal strains discovered, which are potentialistic paclitaxel producer at bioprocess level, can be the game changer.

\section{Why Paclitaxel of Fungal Origin}

The limitation and disadvantages of paclitaxel from plant origin especially yew trees are that the large number of plants destroyed and these plants grown again to harness the compound. This is a time consuming process [1-7]. Scientist therefore switching to explore the fungal strains which are potentialistic paclitaxel producers. Since natural production of compound from the endophytic fungal strains is an organic process that is why there will not be any side effect. This is the major idea in the researchers mind.

\section{Paclitaxel Producing Fungal Strains}

A large number of fungi are potentialistic paclitaxel producers listed below [1-7] (Table 1).

\begin{tabular}{|c|c|}
\hline Taxon & Strain number \\
\hline Taxomyces species & HQ33 \\
\hline Alternaria taxi & HD1353 \\
\hline Alternaria alternate & TPF6 \\
\hline Rhizoctoniaspecies & Tax-1 \\
\hline Botrytis species & Tax-X \\
\hline
\end{tabular}




\section{Journal of Natural \& Ayurvedic Medicine}

\begin{tabular}{|c|c|}
\hline Trichodermaspecies & Tax-23 \\
\hline Chaetomium species & Tax-60 \\
\hline Penicillium species & 12.3 .2 \\
\hline Pestalotiopsis species & F1 \\
\hline Mucor species & Tax-56 \\
\hline Aspergillus species & HD86-9 \\
\hline Fusarium species & F2 \\
\hline Fusarium mairei & UH23 \\
\hline Phyllosticacitricarpa & - \\
\hline Pestalotiopsis pauciseta & CHP-11 \\
\hline Fusarium solani & - \\
\hline Botryodiplodiatheobromae & BT115 \\
\hline Cladosporium species & MD2 \\
\hline Phomamedicaginis & - \\
\hline
\end{tabular}

Table 1: Potentialistic Paclitaxel producers list.

\section{Future Research and Challenges}

In the coming future the potentialistic paclitaxel producing fungal strains at bioprocess level will be identified at large scale and patented. But still there are certain challenges or bottleneck to obtain high yield of paclitaxel from the fungal strains for example the genes or loci to be identified, their expression and regulation to be discovered in-vitro.

\section{References}

1. Jian Z, Li M, Hu X (2017) An endophytic fungus efficiently producing paclitaxel isolated from Taxuswallichiana var. mairei. Medicine 96(27): e7406.

2. Lasala JM, Stone GW, Dawkins KD (2006) An overview of the taxus; express, paclitaxel-eluting stent clinical trial program. J Intervenous Cardiology 19(5): 422-431.

3. Dai WL, Tao WY (2008) Preliminary study on fermentation conditions of taxol-producing endophytic fungus. Chem Ind Eng Prog 27: 883-886.
4. Dejong JM, Liu Y, Bollon AP, Long RM, Jennewein S (2006) Genetic engineering of taxol bio-synthetic genes in Saccharomyces cerevisiae. Biotechnol Bioeng 93(2): 212-224.

5. Dhawale SS, Paietta JV, Marzluf GA (1989) A new, rapid and efficient transformation procedure for Neurospora. Curr Genet 8(1): 77-79.

6. Frense D (2007) Taxanes: perspectives for biotechnological production. Appl Microbiol Biotechnol 73(6): 1233-1240.

7. Gangadevi V, Muthumary J (2009) Anovelendo phytictaxol-producing fungus Chaetomellaraphigera isolated from a medicinal plant, Terminaliaarjuna. Appl Biochem Biotechnol 158: 1599-0291.

8. Gangadevi V, Murugan M, Muthumary J (2008) Taxol determination from Pestalotiopsis pauciseta, a fungal endophyte of a medicinal plant. Chin J Biotech 24(8): 1433-1438.

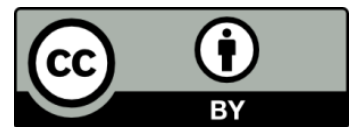

